\title{
STUDI KUALITATIF: PENGALAMAN ADAPTASI IBU HAMIL
}

\author{
Ratu Kusuma \\ Program Studi Profesi Ners STIKes Baiturrahim Jambi \\ Email: ratukusuma1975@gmail.com
}

\begin{abstract}
Pregnant women will experience various changes during pregnancy such as physiological, psychological and social changes. The inability of mothers to adapt to these changes not only causes disruption during pregnancy, but also it can continue in the postpartum period, one of them is postpartum depression. This study aimed to explore the experiences of adaptation of pregnant women, includes perceived stimulus, coping used and adaptation behavior responses indicated by pregnant women. This is a qualitative research by using phenomenology approach at the public health center in Kabupaten Kampar, Riau. Participants in this study were 9 pregnant women, aged 24-38 years, Junior High School-Graduate Education, gestational age 5-29 weeks, the number of children living 1-5 people, children rank age 9 months to 3.5 years, work varies, namely housewives, corporate employees, honors teachers and traders. The collecting data of indepth interview method and observations, recorded using a tape recorder, and then took notes the results of these observations. Based on the data obtained that 7 themes namely 1) Depressive symptoms in pregnant women; 2) Complaints of pregnant women related to nutritional intake; 3) Health problems of pregnant women; 4) Family problem 5) family financial problems 6) coping used by pregnant women 7) adaptive behavioral responses of pregnant women. There were various stimuli felt by pregnant women, namely physiological, psychological and social stimuli. Coping used by pregnant women in reducing the perceived stimulus that was adaptive and not adaptive coping, while the adaptation behavior response indicated by pregnant women was response to physiological adaptation behavior, self-concept, role function and interdependent. Therefore, it is necessary to develop models in the form of providing education to couples of pregnant women in helping mothers adapt, in an effort to prevent the occurrence of postpartum depression.
\end{abstract}

Keywords: Adaptation of pregnant women, stimulus, coping, behavioral adaptation response, postpartum depression.

\begin{abstract}
ABSTRAK
Ibu hamil mengalami berbagai perubahan pada masa kehamilannya seperti perubahan fisiologis, psikologis dan sosial. Ketidakmampuan ibu beradaptasi terhadap perubahan tersebut tidak hanya menyebabkan gangguan pada masa kehamilan, tetapi dapat berlanjut pada masa postpartum, salah satunya adalah depresi postpartum. Penelitian ini bertujuan mengeksplorasi pengalaman adaptasi ibu hamil, meliputi stimulus yang dirasakan, koping yang digunakan serta respons perilaku adaptasi yang ditunjukkan. Penelitian kualitatif ini menggunakan pendekatan fenomenologi, di 6 wilayah kerja puskesmas di Kabupaten Kampar Provinsi Riau. Partisipan adalah 9 orang ibu hamil, usia 24-38 tahun, pendidikan SMP-Sarjana, usia kehamilan 5-29 minggu, jumlah anak hidup 1-5 orang, usia anak 9 bulan sampai dengan 3.5 tahun, pekerjaan bervariasi yaitu ibu rumah tangga, karyawati perusahaan, guru honor dan pedagang. Pengumpulan data melalui indepth interviews dan observasi, direkam menggunakan tape recorder, dan pencatatan hasil observasi. Menghasilkan 7 tema 1) gejala depresi pada ibu hamil; 2)
\end{abstract}


keluhan ibu hamil berkaitan dengan asupan nutrisi; 3) masalah kesehatan ibu hamil; 4) masalah keluarga; 5) masalah keuangan keluarga; 6) koping yang digunakan ibu hamil serta; 7) respons perilaku adaptasi ibu hamil. Berbagai stimulus yang dirasakan oleh ibu hamil adalah stimulus fisiologis, psikologis dan sosial. Koping yang digunakan ibu hamil yaitu koping adaptif dan tidak adaptif, sedangkan respons perilaku adaptasi yang ditunjukkan ibu hamil adalah respons perilaku adaptasi fisiologis, konsep diri, fungsi peran dan interdependen. Oleh karena itu, perlu pengembangan model berupa pemberian edukasi kepada ibu hamil dan suami dalam membantu ibu beradaptasi, untuk mencegah terjadinya depresi postpartum.

Kata Kunci: Adaptasi ibu hamil, stimulus, koping, respons perilaku adaptasi, depresi postpartum.

\section{PENDAHULUAN}

Kehamilan merupakan kondisi yang menyenangkan karena tidak semua wanita yang telah menikah bisa hamil dan melahirkan, namun pada sebagian wanita menganggap masa kehamilan sebagai masa yang tidak menyenangkan dan penuh dengan beban karena ketidakmampuan beradaptasi terhadap berbagai perubahan yang terjadi pada masa kehamilan. Kehamilan dianggap sebagai peristiwa yang dapat menimbulkan stres karena adanya tuntutan penyesuaian diri akibat berbagai perubahan yang terjadi selama kehamilan (Stone \& Menken, 2008).

Perubahan yang dialami ibu pada masa kehamilan adalah perubahan fisiologis, psikologis dan sosial. Perubahan fisiologis seperti perubahan organ reproduksi yaitu uterus, ovarium, vagina, serviks dan payudara. Perubahan juga terjadi pada berbagai sistem seperti sistem kardiovaskuler, sistem pernapasan, sistem pencernaan, sistem integumen, sistem muskuloskletal, sistem persyarafan, dan sistem endokrin. Sebagian besar perubahan tersebut dipengaruhi oleh sistem endokrin melalui kerja hormon (Reeder, Martin \& Griffin, 2011; Pillitteri, 2010). Perubahan psikologis merupakan respons emosional yang terjadi akibat adanya perubahan fisiologis tubuh disertai adanya tanggung jawab yang semakin besar dalam menghadapi beberapa hal baru akibat kehamilan. Perubahan sosial yang terjadi pada ibu hamil adalah adanya perubahan peran dari peran sebagai istri menjadi peran sebagai istri dan peran sebagai ibu. Berbagai perubahan tersebut penting untuk melindungi berbagai fungsi ibu hamil dalam menyediakan berbagai kebutuhan janin terutama bagi pertumbuhan dan perkembangan janin selama didalam kandungan (Pillitteri, 2010; Bobak, Lowdermilk \& Jensen, 2005).

Perubahan yang terjadi pada trimester pertama kehamilan terjadi peningkatan beberapa hormon reproduksi seperti estrogen, progesteron, relaksin, dan somatomamotropin. Hal ini terjadi 
karena trimester pertama merupakan fase organogenesis atau fase pembentukan organ-organ janin, pada fase ini dibutuhkan lingkungan biologis ibu hamil yang mendukung. Efek dari peningkatan hormon tersebut adalah peningkatan vaskularisasi ke berbagai organ seperti rahim, payudara, vagina yang sangat berguna bagi pertumbuhan dan perkembagan janin. (Perry, Hockenberry, Lowdermilk \& Wilson, 2010). Berbagai perubahan tersebut bervariasi pada setiap trimester kehamilan.

Trimester pertama merupakan masa ketidaknyamanan bagi ibu hamil, karena pada masa ini terjadi perubahan fisiologis seperti peningkatan kebutuhan oksigen janin. Upaya memenuhi kebutuhan tersebut, tubuh ibu berkompensasi dengan meningkatkan suplai oksigen ke janin. Oleh karena itu, darah ibu akan mengalirkan lebih banyak oksigen ke janin sehingga ibu hamil berisiko mengalami anemia sehingga ibu merasa pusing, gangguan penglihatan dan mudah lelah, gangguan beraktifitas, dan lainnya (Pillitteri, 2010). Trimester pertama juga terjadi pertumbuhan tulang dan otot sehingga ibu lebih banyak membutuhkan kalsium dan zat besi. Perlu dihindari penggunaan zat atau bahan yang berbahaya termasuk obatobatan (Migl, 2009). Penelitian Beck dan Driscoll, 2006 melaporkan walaupun ibu hamil dari awal telah merencanakan kehamilannya, menerima serta menikmati masa kehamilannya bukan berarti ibu tersebut terhindar dari berbagai masalah psikologis seperti rasa cemas, takut, kebingungan bahkan depresi. Hal tersebut terjadi karena pada trimester pertama ibu hamil mengalami kebingungan atau ambivalen tentang diagnosa kehamilannya, apakah dirinya benarbenar hamil atau tidak.

Pergerakan janin yang mulai dirasakan ibu memberikan perasaan senang sehingga ibu yakin bahwa sekarang dirinya benar-benar hamil. Hal ini membuat ibu akan terfokus pada kehamilannya dan mulai mempersiapkan peran barunya sebagai seorang ibu. Perubahan tersebut meningkatkan risiko ibu hamil mengalami masalah psikologis misalnya kesedihan karena harus meninggalkan perannya sebelum hamil. Kondisi ini sebagian besar terjadi pada ibu primigravida dan wanita karir. Selain itu, sebagian ibu hamil merasa takut jika suaminya kurang atau tidak lagi menyayangi dirinya seperti dulu karena terlihat gendut dan tidak menarik lagi (Reeder, Martin \& Griffin, 2011; Bobak, Lowdermilk \& Jensen, 2005).

Trimester kedua merupakan masa dimana ibu hamil mulai mengevaluasi segala aspek dirinya, termasuk bagaimana hubungannya dengan orang lain diluar dirinya dan keluarga misalnya orangtua, saudara, teman atau tenaga kesehatan. Hal ini dimanfaatkan ibu untuk mencari informasi atau pengalaman tentang peran menjadi ibu dan menghadapi persalinan. Mulai menerima nilai-nilai yang ada dimasyarakat dalam upaya mengembangkan identitas keibuannya. Alfonso (2003), proses ini merupakan perubahan identitas dari menerima kasih sayang 
menjadi pemberi kasih sayang kepada anaknya nanti.

Trimester ketiga merupakan masa penantian dan kewaspadaan bagi ibu karena tidak sabar menanti kelahiran bayi, serta masa dimana ibu akan mulai menjalani perannya sebagai ibu. Ibu hamil berisiko mengalami berbagai masalah fisiologis, psikologis ataupun sosial. Masalah fisiologis seperti sesak nafas akibat pembesaran rahim menekan diafragma, hipertensi yang berdampak terhadap preeklamsi dan eklamsia serta asma yang terjadi akibat aktifasi dari sistem imunitas ibu hamil. hal tersebut memberikan dampak buruk kepada pertumbuhan dan perkembangan janin (Migl, 2009; Perry, Hockenberry, Lowdermilk \& Wilson, 2010). Ibu hamil merasakan khawatir apabila bayinya lahir sewaktu-waktu, hal ini menyebabkan ibu merasa cemas. Rasa cemas juga dapat disebabkan oleh kekhawatiran ibu terhadap kondisi atau kesehatan janinnya atau kesulitan dalam proses persalinannya. Pillitteri (2010) ketidaknyamanan yang kembali terjadi pada trimester tiga memberikan masalah psikologis bagi ibu misalnya ibu merasa aneh dengan dirinya, kelihatan jelek dan tidak menarik.

Ibu hamil diharapkan dapat menerima dan beradaptasi terhadap segala perubahan fisiologis, psikologis dan sosial yang terjadi pada dirinya secara realita dan tanpa adanya tekanan dengan cara meningkatkan kesehatan fisik dan psikologisnya. Ibu hamil yang tidak bisa beradaptasi terhadap berbagai perubahan tersebut menunjukkan gejala gangguan psikologis seperti stres atau depresi (Perry, Hockenberry, Lowdermilk \& Wilson, 2010). Revarubin dan Alfonso (2003 seorang ibu hamil akan selalu memperhatikan setiap detail perubahan pada dirinya, hal tersebut berisiko menyebabkan fantasi dan ketakutan selama kehamilannya serta merasa khawatir terhadap perubahan fisik dan psikologisnya. Boscaglia, Skouteris dan Wertheim (2002) sebagian ibu merasa tidak nyaman dengan perubahan tubuhnya akibat kehamilan, dan hal ini memberikan risiko terjadinya depresi.

Penenitian ini bertujuan untuk mengidentifikasi berbagai masalah yang dialami ibu selama kehamilannya.

\section{METODE PENELITIAN}

\section{Lokasi Penelitian}

Dilakukan di 6 wilayah kerja puskesmas di Kabupaten Kampar yaitu Kecamatan Bangkinang Kota, Bangkinang, Tapung I, Kuok, Salo dan Kampar.

\section{Desain Penelitian}

Merupakan penelitian fenomenologi, dimana peneliti menggali pengalaman partisipan dalam beradaptasi terhadap berbagai perubahan yang terjadi dalam kehamilannya. Pengalaman tersebut, teridentifikasi dari respons verbal dan non verbal partisipan yang menghasilkan 7 tema.

\section{Partisipan}

Partisipan pada penelitian ini adalah ibu hamil yang dipilih berdasarkan teknik purposive sampling, sebanyak 9 orang ibu hamil. Ditentukan berdasarkan saturasi data, dimana 
pengambilan data akan dihentikan setelah tercapainya saturasi data atau tidak ditemukan lagi data yang baru (Barr \& Beck, 2008).

\section{Instrumen Penelitian}

Menggunakan instrumen pedoman wawancara tidak terstruktur, yang dirancang oleh peneliti berdasarkan tujuan penelitian (Afiyanti \& Rachmawati, 2014), digunakan untuk menggali informasi secara mendalam tentang pengalaman ibu hamil dalam beradaptasi yang meliputi stumulus, koping dan respons perilaku adaptasi, yang terdiri dari 49 pertanyaan.

\section{Pengumpulan Data}

Pengumpulan data dilakukan dengan metode indepth interviews dan observasi. Wawancara mendalam tentang stimulus, koping dan respons perilaku ibu hamil, dilakukan tidak terstruktur sehingga pertanyaan yang diajukan bersifat fleksibel namun tidak menyimpang dari tujuan penelitian. Dicatat dan direkam menggunakan tape recorder. Observasi merupakan metoda pengumpulan data dengan cara mengamati semua perilaku subjek penelitian, kemudian melakukan pencatatan terhadap hasil observasi (Afiyanti \& Rachmawati, 2014; Creswell, 2013; Creswell, 2009). Observasi dilakukan terhadap perilaku yang ditampilkan ibu hamil dari awal sampai berakhirnya wawancara. Hasil keduanya didokumentasikan pada catatan lapangan.

\section{Validitas Data}

Validitas data dilakukan melalui triangulasi data dengan teknik member check atau feedback partisipan, dimana peneliti mencocokkan kembali pemahaman dan interpretasi data kepada pemahaman partisipannya.

\section{Pengolahan dan Analisis Data}

Pengolahan data dilakukan secara manual karena jumlah informan penelitian kualitatif ini biasanya tidak banyak. Analisis data dilakukan bersamaan dengan proses pengumpulan data (Boyatzis, 1998 dalam Poerwandari, 2009).

Data kualitatif dari wawancara mendalam dibuat transkrip dengan cara memindahkan data kedalam bentuk tulisan. Selanjutnya, dilakukan cleaning data, data diolah secara manual dengan mengecek kembali data secara detail dan menyeluruh terhadap semua data yang diperoleh. Triangulasi data dan sumber juga dilakukan untuk menjaga validitas data. Teknik triangulasi data yang dilakukan pada penelitian ini adalah pemeriksaan dengan membandingkan antar partisipan yang berbeda secara karakteristik. Langkah selanjutnya adalah analisis data dengan menggunakan analisis tema. Analisis tema merupakan proses mengkode informasi yang dapat menghasilkan daftar tema yang kompleks. Setelah semua langkah dilakukan, maka didapatkan 7 tema yang berhubungan dengan pengalaman adaptasi ibu hamil.

\section{HASIL DAN PEMBAHASAN}

Analisis data secara kualitatif menghasilkan 7 tema, yaitu:

\section{Tema-1:}

"Gejala Depresi pada Ibu Hamil" 
Partisipan mengungkapkan gejala depresi yang dialaminya dalam 15 kategori, antara lain diungkapkan oleh partisipan berikut:

“...begitu ketahuan hamil, saya langsung panik...(P5)”

“...sedih karena suami tidak peduli dengan saya dan anak-anak (Pl)"

"...kehamilan ini tidak saya inginkan, karena anak saya sudah 5 orang $(P 2)$ "

"...saya tidak menginginkan anak ini buk, maunya digugurkan...(P1),

“...terpikir untuk ngasih anak ini ke orang, biarlah dirawatnya...(P3)"

"...saya coba gugurkan dengan makan obat yang saya beli di apotik (P6)"

Hasil observasi pada partisipan 1 dan 2: memperlihatkan wajah sedih dan murung. Partisipan 1 dan 6: menunduk sambil menangis dan menghapus air matanya dengan bajunya. Partispan 3 menagis terisak-isak terutama ketika menceritakan tentang kondisi suaminya yang sedang sakit.

Gejala depresi yang paling menonjol pada penelitian ini seperti melakukan upaya mengahiri kehamilannya dengan berbagai cara meminum jamu tradisional, pijat (kusuk) ke dukun beranak, meminum perasan air nenas dicampur ragi. Berbagai upaya tersebut dilakukan oleh enam partisipan (P1, P2, P3, P4, P5 dan P6), namun satu diantaranya (P6) bahkan mengkonsumsi obat medis yaitu obat yang dibeli oleh partisipan di apotik. Teori Green mengatakan bahwa perilaku pada dasarnya adalah tindakan manusia, dipengaruhi oleh banyak faktor seperti pendidikan, pengetahuan, sikap, budaya, persepsi, atau ketersediaan sarana dan sarana (Notoatmodjo, 2010). Perilaku partisian 1 sampai 5 dalam upaya menggugurkan kehamilannya kemungkinan disebabkan oleh rendahnya pendidikan, kurangnya pengetahuan terkait bahaya aborsi, karena partisipan hanya berpendikan SMP dan SMA. Semakin tinggi pendidikan atau pengetahuan seseorang tidak menjamin seseorang tersebut akan berperilaku yang positif, dibuktikan oleh perilaku partisipan enam (P6) berpendidikan D3 kebidanan, melakukan upaya menggugurkan kehamilannya dengan mengkonsumi obat medis. Terjadinya perilaku aborsi ini diduga karena partisipan mengetahui cara menggugurkan dan mudahnya untuk memperoleh obat tersebut.

Penelitian ini didukung oleh penelitian O'hara (2009), salah satu gejala depresi pada masa perinatal antara lain seperti pikiran kacau dan kadang disertai dengan munculnya halusinasi berupa ide mencederai janin. Sutjahyo, Manderson dan Astbury (2007), sebagian besar ibu hamil melakukan upaya menggugurkan kehamilan misalnya dengan minum jamu tradisional. Fisher, et al (2010) bahwa diantara beberapa gejala depresi yang dialami ibu hamil adalah munculnya pikiran untuk mencederai janinya.

Sebagian besar partisipan penelitian ini mengalami berbagai gejala depresi dalam kehamilan. Gejala depresi lebih banyak muncul pada kehamilannya yang tidak diinginkan, suami tidak bekerja atau tidak memilik pekerjaan tetap dan suami yang kehilangan akibat dipecat dari 
pekerjaannya, atau suami yang sedang sakit. Gejala depresi tersebut dipengaruhi oleh berbagai faktor seperti pekerjaan suami, tidak/kurang harmonisnya hubungan ibu dengan suami, jumlah dan usia anak yang masih kecil.

\section{Tema-2:}

\section{"Keluhan Ibu Hamil Berkaitan dengan Asupan Nutrisi"}

Keluhan tentang asupan nutrisi yang diungkapkan oleh partisipan tergambar pada 8 kategori, antara lain diungkapkan oleh partisipan:

“...mual dan muntah, paling terasa pagi setelah bangun tidur (P5)",

"karena tidak ada uang, saya makan seadanya, kadang makan ubi saja (P3)"

"...sejak kehamilan ini berat badan saya turun $4 \mathrm{~kg}$, tadinya $50 \mathrm{~kg}$ (P2)"

“...aku sering pusing, rupanya tensiku turun jadi 80 biasanya 120 (P3)".

Keluhan ibu hamil berkaitan dengan asupan nutrisi yang dialami oleh ibu hamil yaitu mual dan muntah, kurang asupan makanan, penurunan nafsu makan, penurunan berat badan, kurus, pucat, pusing atau sakit kepala, dan penurunan tekanan darah. Sebagian besar partisipan mengalami mual muntah dalam batas normal karena tejadi pada pagi saja hari dan hanya pada trimester pertama kehamilannya. Mual dan muntah yang dialami ibu berdampak terhadap penurunan nafsu makan sehingga terjadi penurunan berat badan. Hasil penelitian ini didukung oleh Nicolson (2010), gangguan nutrisi yang terjadi dalam kehamilan dapat berdampak pada penurunan berat badan ibu hamil. Migl (2009) yang menyatakan bahwa beberapa ibu hamil mengalami mual, muntah.

Penurunan asupan makanan tidak hanya disebabkan oleh mual dan muntah atau penurunan nafsu makan saja, hal yang berbeda disampaikan oleh partisipan tiga (P3), dimana asupan makanan terjadi karena tidak tersedianya makanan yang akan dikonsumsi partisipan, ".karena tidak ada uang, saya makan seadanya, kadang cuma makan ubi saja". Perilaku partisipan ini sesuai dengan toeri Green, bahwa salah satu faktor yang menghalangi terjadinya perubahan perilaku adalah faktor sarana dan prasarana (Notoatmodjo, 2010) .Ketidaktersediaan bahan makanan yang akan dikonsumsi membuat partisipan (P3) menunjukkan perilaku yang kurang tepat bagi seorang ibu hamil.

Keluhan nutrisi lebih banyak diungkapkan oleh partisipan yang mengalami stres karena kehamilan yang tidak diinginkan, mengalami mual muntah dan penurunan nafsu makan. Kurangnya asupan nutrisi juga disebabkan oleh ketidaktersediaan makanan atau bahan makanan yang akan dikonsumsi partisipan. Kurangnya asupan nutrisi sebagian besar berpengaruh terhadap penurunan berat badan dan kesehatan fisik partisipanl, dan partisipan tampak pucat.

\section{Tema-3:}

\section{"Masalah Kesehatan Ibu Hamil"}

Masalah kesehatan yang pernah atau sedang dialami oleh partisipan tergambar pada 3 kategori, dibuktikan oleh ungkapan partisipan:

"...saya pernah menderita tumor payudara...(P4)” 


\begin{abstract}
“...anak pertama saya lahirnya dioperasi karena panggul sempit...(P1)"

“...kondisi saya sekarang ini kurang sehat, $\quad$ flu...batuk...agak demam...(P4)"

"...sekarang ini punggungku sakit, dan sudah beberapa hari ini kemaluanku ini sakit, mungkin karena hamilku sudah besar...(P3)",
\end{abstract}

Hasil observasi terhadap partisipan 3: partisipan memegang punggung dan daerah simpisisnya ketika menceritakan punggung dan simpisisnya sering sakit.

Partisipan pada penelitian ini memiliki riwayat masalah kesehatan seperti pernah menderita tumor payudara, pernah menderita penyakit tiroid dan penyakait koloid. Riwayat obstetrik seperti melahirkan dengan tindakan sectio cesarean (SC), infeksi pada bekas SC, panggul sempit dan partus lama. Masalah kesehatan yang dialami ibu hamil saat ini seperti flu, batuk, demam, sakit pinggang dan simpisis. Partisipan 4 (P4) mengungkapkan bahwa diusianya yang baru 26 tahun sudah 4 kali dilakukan operasi (2 kali operasi pengangkatan tumor payudara dan 2 kali SC). Kondisi ini berpengaruh pada kondisi fisik partisipan saat ini seperti sering mengalami flu, batuk, sering demam. Berpengaruh juga pada kondisi psikologis misalnya sering merasa sedih, menangis, cemas dan bingung menghadapai kehamilannya.

Beck, Reynold dan Rutoewski (2013) melaporkan bahwa riwayat penyakit ibu seperti penyakit jantung, tiroid dan penyakit lainnya, riwayat depresi dalam keluarga dan riwayat depresi ibu hamil merupakan risiko terhadap kejadian depresi perinatal. Fisher, et al (2010), gangguan kesehatan seperti hipertensi berpengaruh terhadap kejadian depresi dalam kehamilan dan postpartum.

Sebagian partisipan mengalami masalah kesehatan seperti memiliki riwayat tumor payudara, penyakit tiroid, penyakait koloid, persalinan dengan sectio cesarean dengan indikasi panggul sempit dan partus lama. Sebagian lainnya mengalami flu, batuk, demam, sakit pinggang dan sakit pada simpisis. Masalah kesehatan yang terjadi pada partisipan ini adalah masalah yang umum terjadi pada ibu hamil. Partisipan yang memiliki masalah kesehatan mengungkapkan gejala depresi yang lebih banyak dibanding partisipan dengan kondisi kesehatan yang lebih baik.

\section{Tema-4:}

\section{"Masalah Keluarga Ibu Hamil"}

Masalah keluarga juga memperberat masalah yang dialami partisipan, tergambar pada 7 kategori, diungkapkan oleh beberapa patisipan:

“...anakku sudah banyak buk, sudah 5 orang sementara suamiku sekarang ini sakit, tidak bisa cari makan...(P3)",

“...suami saya keberatan saya hamil lagi, dia menyuruh menggugurkannya...(P2)”

“...suami saya sering pulang subuh, kadang malah tidak pulang...(P1)”

"...kabarnya suami saya pacaran, dan sering mangkal di kafe (P2)”

Masalah keluarga yang dialami partisipan adalah usia anak yang 
masih kecil (9 bulan), jumlah anak yang banyak (5 orang). Faktor yang paling banyak diungkapkan oleh partisipan adalah kurangnya dukungan suami atau orang terdekat lainnya. Suami yang tidak mendukung kehamilannya, bahkan salah satu suami yang menyuruh partisipan untuk menggugurkan kehamilannya. Faktor kurangnya perhatian dan kurangnya berkomunikasi dengan suami juga memperberat kondisi fisik dan psikologis yang dialami partisipan. Perilaku lainnya seperti suami sering pulang subuh atau tidak pulang sama sekali atau pulang setelah 2-3 hari kemudian, sering dimarahi suami, suami sering pergi ke kafe dan memiliki wanita lain. Fisher, et al (2010), salah satu faktor yang menyebabkan terjadinya depresi perinatal adalah buruknya hubungan dengan suami.

Kurangnya dukungan orang terdekat seperti orangtua, mertua, dan saudara juga memperberat kondisi partisipan. Sutjhahjo, Manderson dan Astrbury (2007) melaporkan bahwa faktor keluarga yang berpengaruh terhadap kehamilan antara lain kurangnya dukungan orang terdekat seperti orangtua atau mertua, kondisi kesehatan anggota keluarga (anak yang sering sakit-sakitan, bahkan salah satu diantara anak mengalami kebutaan, kondisi suami yang sedang sakit/lumpuh). Penelitian Sutjahyo, Manderson dan Astbury (2007), beberapa faktor penyebab terjadinya perubahan emosional pada ibu hamil yaitu kondisi kesehatan anggota keluarga lainnya atau penyakit tertentu yang diderita dalam keluarga.
Sebagian besar partisipan mengalami berbagai macam masalah keluarga, berbagai masalah keluarga yang dialami partisipan berpengaruh terhadap kondisi fisik dan psikologisnya. Partisipan yang memiliki lebih banyak masalah keluarga juga menunjukkan gejala depresi yang lebih banyak dibanding partisipan dengan masalah keluarga yang lebih sedikit.

\section{Tema-5:}

"Masalah Keuangan Keluarga Ibu Hamil"

Keuangan keluarga merupakan faktor yang memperberat masalah yang dialami partisipan, tergambar dari 5 kategori, dibuktikan oleh:

“...satu tahun ini suami saya tidak bekerja, tadinya polisi...dipecat, sekarang makan dari mertua...(P5)",

"...sejak suamiku sakit, tidak ada yang cari uang lagi, palingan juga aku ngurut, itupun kalau ada dan hasilnya juga tidak seberapa buk...(P3)"

Masalah keuangan keluarga dialami oleh sebagian besar partisipan, kondisi yang paling berat terjadi pada partisipan dua (P2), memiliki 5 anak dan 3 diantaranya sudah sekolah, sedangkan penghasilan keluarga tidak pasti karena suami tidak memiliki pekerjaan tetap. Sumber keuangan lain hanyalah hasil usaha warung dengan penghasilan yang 30-50 ribu perhari. Partisipan tiga (P3), dengan jumlah anak 5 orang dan beberapa diantaranya sudah sekolah, tidak memiliki sumber penghasilan tetap karena suami sedang sakit/lumpuh, dan anak sulung yang biasanya membantu mencari nafkah mengalami kebutaan. Sumber 
penghasilan keluarga saat ini berasal dari pendapatan partisipan sebagai tukang pijat tradisional. Partisipan lima (P5), suami baru saja kehilangan pekerjaannya karena dipecat dari anggota kepolisian. Sumber keuangan keluarga saat ini berasal dari mertua. Permasalahan ekonomi yang dialami masingmasing partisipan memperberat kondisi psikologinya.

Penelitian Beck, Reynold dan Rutoewski (2013) melaporkan bahwa faktor pendapatan keluarga yang rendah dengan jumlah anak yang banyak berpengaruh terhadap kejadian depresi pada masa perinatal. Sutjahyo, Manderson dan Astbury (2007), faktor ekonomi seperti kemiskinan, suami yang tidak bekerja dan penghasilan keluarga yang tidak mencukupi berkontribusi terhadap perubahan emosional ibu selama kehamilan.

Sebagian besar partisipan mengalami masalah keuangan dalam keluarganya, terutama terjadi pada partisipan yang memiliki anak yang lebih banyak sedangkan suaminya tidak memiliki pekerjaan tetap. Pada Partisipan ini juga menunjukkan gejala depresi yang lebih banyak dibanding partispan dengan perekonomian keluarga yang lebih baik. Masalah keuangan keluarga juga berpengaruh kepada asupan nutrisi dan kondisi kesehatan ibu hamil.

\section{Tma-6:}

\section{"Koping yang digunakan Ibu Hamil"}

Secara umum terdapat 2 macam koping yang digunakan oleh ibu hamil dalam mengatasi masalah yang sedang dialaminya yaitu koping adaptif dan tidak adaptif. Koping yang digunakan ibu hamil tergambar dalam 4 kategori yaitu psikologis, koping fisiologis, spritual dan koping tidak adaptif:

Koping psikologis yang digunakan oleh ibu hamil:

“...saya bersyukur karena suami saya mendengarkan apa yang saya keluhkan dan memberikan solusinya...(P7)"

Koping fisiologis yang dilakukan ibu hamil:

“...untuk mengurangi beban pikiran, palingan saya menyetrika pakaian...menyapu...menyiang rumput...(P4)"

Koping spritual yang dilakukan ibu hamil diungkapkan oleh partisipan berikut:

"...shalat tahajjud, sebelum tidur saya shalat tahajjud dulu...(P6)",

"...selalu berdo'a agar suami saya cepat sembuhnya, bisa bekerja seperti dulu, bisa cari uang lagi...berdo'a agar anak-anak saya sehat ...(P3)"

Selain koping adaptif terdapat juga koping tidak adaptif:

"takut bercerita ke orang lain, nantinya saya disalahkan karena anak sudah banyak, umur sudah tua... makanya saya pendam saja (P2)"

"...malas keluar rumah buk, lebih baik dirumah saja dengan anakanak (P1)“

Bercerita kepada suami dan orang terdekat lainnya (orangtua terutama ibu, saudara kandung, tante, teman, tetangga, dan tenaga kesehatan) merupakan koping psikologis yang dilakukan partisipan pada penelitian ini. Selain itu, partisipan juga 
berkumpul dengan keluarga seperti mengunjungi orangtua/mertua, dan saudara lainnya termasuk berkumpul dengan teman ata utetangga. Upaya ini dilaporkan dapat mengurangi stres atau beban pikiran yang dialami oleh partisipan. Penelitian Migl (2009) melaporkan bahwa salah satu koping psikologis ibu hamil dalam mengatasi masalah yang dialaminya adalah bercerita kepada suami, orangtua atau saudara lainnya. Sutjahyo, Manderson dan Astbury (2007) bahwa sebagian ibu hamil mengatakan selalu bersama suami dan bercerita kepada suami tentang masalah yang dialaminya, hal tersebut membuat ibu merasa lebih tenang.

Pada penelitian ini, sebagian besar partisipan tetap melaksanakan tugasnya sebagai ibu rumah tangga seperti memasak, menyetrika pakaian, menyapu atau menyiang rumput di halaman, mengurus anak dan suami. Hal lain yang dilakukan adalah menonton televisi, mendengarkan musik, istirahat atau tidur siang minimal 1 jam untuk mengurangi kelelahannya dan kadang-kadang meminta bantuan suami untuk memijatnya. Penelitian Migl (2009), beberapa upaya yang dapat dilakukan oleh ibu hamil untuk mengatasi masalah fisik dan emosional adalah istirahat dan tidur yang cukup, olahraga atau aktifitas fisik lainnya. Mukaino (2005) pijat tradisional dapat mengurangi gejala gangguan seperti mual muntah, nyeri ulu hati, gangguan tidur, dapat memperbaiki letak janin dalam kandungan serta dapat mencegah depresi pada masa kehamilan.
Stuart dan Laraia (2013) seseorang yang mengalami perasaan tidak tentram, cemas dan stes psikologis jika melakukan latihan relaksasi yang terprogram secara baik maka berpotensi menurunkan denyut nadi, menurunkan tekanan darah tinggi, mengurangi frekuensi napas sehingga efektif dalam mengatasi kecemasan. Parry, et al (2010) lamanya waktu tidur pada ibu hamil dapat menyebabkan ibu mengalami depresi pada masa kehamilan dan postpartum.

Koping spritual yang dapat dilakukan ibu hamil dalam mengatasi masalahnya adalah dengan mendekatkan diri dengan Tuhan. Semua partisipan pada penelitian ini adalah muslim, koping spritual yang dilakukan oleh beberapa partisipan adalah shalat berjamaah di mesjid terutama shalat magrib, shalat tahajjud, selalu berdo'a dan berserah diri kepada Tuhan, memohon diberi kesehatan kepada semua anggota keluarga dan diberi rezeki dan lain sebagainya. Penelitian Trimulyaningsih (2011) yang melaporkan bahwa terapi kognitif perilaku religius (TKPR) efektif dalam mengatasi depresi. Hartono (2010), mendengarkan ceramah agama dan bimbingan do'a dapat menurunkan gejala depresi.

Selain koping adaptif terdapat juga koping tidak adaptif, koping tidak adaptif yang digunakan partisiapan pada penelitian ini adalah takut bercerita kepada suami, orangtua, atau saudara karena takut disalahkan, sehingga partisipan memilih memendam dan lebih banyak di rumah saja. Beberapa partisipan (P1, P2 dan P6) memilih untuk atau 
memendam sendiri masalahnya atau tidak mengkomunikasikan kepada suami dan orang terdekat lainnya terutama orangtua atau mertua karena takut disalahkan. Hal ini menyebabkan partisipan kurang berinteraksi dengan orang lain dan memilih lebih banyak berada di rumah saja. Penelitian ini didukung oleh studi grounded theory yang dilakukan Beck (2013) bahwa ibu hamil yang tidak mengkomunikasikan masalahnya kepada suami ataupun orang terdekat lainnya cenderung mengalami beberapa gejala depresi seperti cemas, panik, sedih, menangis dengan histeris, marah yang tidak terkontrol, dan kurang konsentrasi serta merasa dirinya seperti orang gila.

Beberapa partisipan telah menggunakan koping adaptif dalam menghadapi masalah yang dialaminya seperti menyampaikan atau menceritakan masalahnya kepada suami atau orang terdekat lainnya. Koping adaptif ini dilakukan oleh partisipan yang memiliki hubungan yang baik dengan pasangannya, sedangkan pada partisipan memiliki hubungan atau kurangnya komunikasi dengan pasangan cenderung memendam masalahnya sendiri. Selain itu, partisipan tetap melakukan tugasnya sebagai ibu rumah tangga dalam mengurus anak dan suami, mengerjakan pekerjaan atau rutinitas rumah tangga dan lain sebagainnya. Pendekatan religi yang dilakukan oleh partisipan juga membantu dalam mengatasi masalah yang dihadapinya, misalnya dengan berserah diri kepada sang pencipta. Analisis terhadap koping yang digunakan partisipan menunjukkan bahwa koping berpengaruh terhadap kemampuan adaptasi ibu hamil.

\section{Tema-7:}

"Respons Perilaku Adaptasi Ibu Hamil"

Respons perilaku adaptasi ibu hamil tergambar pada 4 kategori yaitu respon adaptasi fisiologi, konsep diri, fungsi peran dan interdependen: “...saya tetap makan nasi sama lauk dan sayurnya kak, takut ada apaapanya dengan janin ini. Kalau tidak makan...nanti perkembangannya terganggu...(P5)", "...saya selalu minum susu ibu hamil kalau tidak minum susu takutnya saya dan janin ini kurang gizi...nanti lahirnya prematur...(P7)" Respons adaptasi konsep diri yang dilakukan paertisipan:

“...kenapa harus malu buk, walaupun gendut tidak masalah samaku, namanya juga orang lagi hamil...(P3)”

"...memang sich..sekarang saya gemuk kak, berat badan saya naik sekitar 11 kilo, tapi itu ndak masalah... wajarlah karena saya hamilnya sudah masuk 8 bulan juga...(P5)"

Respons adaptasi fungsi peran yang dilakukan partisipan:

“...kehamilan ini tidak mengganggu pekerjaan saya, setiap hari tetap mengajar seperti biasa...(P8)"

"...setiap minggu saya ikut wirid pengajian buk...P2)”

Respons adaptasi interdependen yang dilakukan partisipan:

“...mengerjakan tugas rumah tangga dibantu suami, misalnya mengasuh anak...memandikan anak... (P7)",

"...walaupun suamiku lagi sakit tapi dia perhatian dan mengerti 
dengan kondisiku buk, dialah yang selalu memberikan semangat buat aku...(P3)"

"...nasehat dan motivasi dokter kandungan itulah satu-satunya yang menjadi semangat saya kak, dia yang memotivasi...(P5)"

Respons adaptasi fisiologis yang dilakukan partisipan ada penelitian ini adalah dengan memenuhi kebutuhan nutrisi. Penelitian Leung, et al (2013), bahwa 99\% ibu hamil yang mengkonsumsi mikronutrien seperti vitamin B6, B9, vitamin E, vitamin $\mathrm{D}$, omega-3 menunjukkan penurunan gejala depresi postpartum. Bowers dan Corwin (2013), bahwa antioksidan yang di konsumsi ibu saat kehamilan dapat mencegah terjadinya depresi postpartum. Mokhber, et al (2011) bahwa pemberian selenium pada usia kehamilan 6 bulan sampai 8 minggu postpartum dapat mengurangi gejala depresi postpartum.

\section{Respons adaptasi konsep diri} yang ditunjukkan partisipan adalah memiliki pandangan positif terhadap diri sendiri, dimana partisipan tidak merasa malu dengan perubahan bentuk tubuh dan penambahan berat badan. Partisipan lima (P5) mengatakan bahwa "walaupun kehamilan ini sebenarnya tidak saya inginkan, tapi perubahan berat badan tidak membuat saya malu, kenapa harus malu? namanya juga orang lagi hamil 8 bulan, gendut tidak masalah. Partisipan tiga (P3) "berat badanku sekarang nambah $10 \mathrm{~kg}$, tapi tidak jadi masalah samaku". Penelitian Revarubin dan Alfonso (2003) seorang wanita yang mengetahui dirinya hamil akan berusaha selalu memperhatikan setiap detail perubahan yang terjadi dalam dirinya. Sebagian wanita merasa senang dan sebagian lagi wanita justru tidak puas dengan perubahan bentuk tubuh sehingga mengalami ketakutan selama menjalani kehamilannya. Boscaglia, Skouteris dan Wertheim (2002) bahwa sebagian ibu hamil tidak puas dengan perubahan tubuhnya akibat kehamilan, kondisi ini berpengaruh terhadap perkembangan psikologis ibu hamil. Elfiky (2010) seseorang yang berpikir positif akan selalu memandang setiap hal dengan positif, menganggap suatu masalah sebagai suatu tantangan, menikmati hidup, terbuka pada saran dan ide, bersyukur dan tidak merasa malu.

Respons adaptasi fungsi peran partisipan pada penelitian ini adalah mengerjakan rutinitas rumah tangga seperti memasak, menyuci pakaian, menyapu dan menurus anak. Mengerjakan tugas sesuai profesi seperti ngantor dan mengajar. Mengikuti kegiatan dimasyarakat seperti mengikuti wirid pengajian dan arisan mingguan atau bulanan. Sebagian besar partisipan tetap melaksanakan tugasnya sebagai ibu rumah tangga dalam mengurus anak dan suami. Bagi partisipan yang memilik pekerjaan lain seperti berdagang, guru honor, karyawan perusahaan tetap bisa melaksanakan tugas tersebut walaupun kadang tidak optimal dibanding sebelum hamil, misalnya ungkapan partisipan delapan (P8) "pernah juga saya tidak masuk kantor (tidak ngajar) karena saya merasa lelah, tapi itu hanya satu hari saja, besoknya saya kembali 
mengajar". Sutjahyo, Manderson dan Astbury (2007) untuk mengatasi stres yang dialaminya, beberapa ibu hamil memilih tetap melakukan aktifitas rutinnya dengan mengerjakan pekerjaan rumah tangga seperti memasak, bekerja dikantor, dan berdagang.

\section{Respons adaptasi interdependen} partisipan pada penelitian ini adalah mendapat bantuan dari anak dan suami dalam mengerjakan pekerjaan/rutinitas rumah tangga. Mendapat bantuan keuangan dari orangtua dan mertua, mendapat perhatian, kasih sayang serta dimotivasi oleh suami, keluarga dan orang lain termasuk tenaga kesehatan seperti dokter kandungan dan bidan. Partispan kedua (P2) mengatakan bahwa setiap harinya dirinya dibantu oleh anak sulungnya seperti menyapu, mencucui piring, menyetrika pakaian dan mengasuh adik-adiknya. Partisipan tujuh (P7) mengatakan bahwa setiap hari dirinya dibantu oleh suami terutama mengasuh anak dan memandikannya. Bantuan lainnya adalah bantuan dalam keuangan, hal ini diungkapkan oleh partisipan lima (P5) "karena suami saya baru saja dipecat dari kepolisian sekarang dia tidak bekerja, mertua yang rutin ngasih uang bulanan". Pryor, et al (2003) bahwa dukungan sosial dari suami dan orang terdekat lainnya berkontribusi terhadap kejadian depresi dalam kehamilan. Croog, (2008) salah satu faktor yang menyebabkan terjadinya depresi pada ibu perinatal adalah tidak adekuatnya dukungan sosial.

Dukungan lain juga diberikan oleh tenaga kesehatan, diungkapkan oleh partisipan lima (P5) "ibu masih beruntung dari ibu-ibu lainnya, ketika dia hamil anaknya masih berumur 3 atau 6 bulan sedangkan usia anak ibu sudah 1 tahun. Canuso (2003), melaporkan bahwa ibu hamil yang mendapatkan suppor group dari perawat menunjukkan penurunan gejala depresi.

Peran dan keterlibatan anggota keluarga terutama suami perlu ditingkatkan karena keluarga merupakan sumber dukungan utama bagi ibu hamil agar ibu mampu beradaptasi terhadap kehamilannya sehingga ibu tidak mengalami masalah psikologis. Berbagai penelitian melaporkan bahwa faktor yang paling banyak menyebabkan depresi pada masa perinatal adalah kurangnya dukungan sosial dari suami dan orang terdekat lainnya (Fitelson, Kim, Baker \& Leight, 2011; Klainin \& Arthur, 2009; Stone \& Menken, 2008; Beck \& Driscoll, 2006).

Partisipan yang mendapatkan dukungan suami dan orang terdekat lainnya menujukkan respons yang efektif dibanding yang kurang atau tidak mendapatkan dukungan. Faktor lain yang mempengaruhi respons perilaku adaptasi ibu hamil adalah pekerjaan suami yang berhubungan keuangan keluarga, status kehamilan yang diinginkan atau tidak, jumlah anak serta usia anak. Analisis terhadap respons perilaku adaptasi menunjukkan bahwa respons perilaku adaptasi yang ditunjukkan oleh partisipan berpengaruh terhadap kemampuan beradaptasinya.

\section{SIMPULAN DAN SARAN}


Penelitian ini menghasilkan 7 tema yaitu 1) gejala depresi pada ibu hamil; 2) keluhan ibu hamil berkaitan dengan asupan nutrisi; 3) masalah kesehatan ibu hamil; 4) masalah keluarga 5) masalah keuangan keluarga; 6) koping yang digunakan serta; 7) respons perilaku adaptasi ibu hamil. Disarankan kepada peneliti lanjut untuk dapat menjadikan hasil penelitian ini sebagai data dasar untuk melakukan penelitian lain terkait dengan kehamilan, dengan metode yang berbeda dari penelitian ini.

\section{DAFTAR PUSTAKA}

1. Afiyanti, Y., \& Rachmawati, I.N. (2014). Metodologi penelitian kualitatif dalam riset keperawatan. Jakarta: PT Raja Grafindo Persada.

2. Barr J.A., \& Beck, C.T. (2008). Infanticide secrets: Qualitative study on postpartum depression. Can Fam Physician, 54, 1-5.

3. Beck. C.T., \& Driscoll, J.W. (2006). Postparum mood and anxiety disorder: A Clinician's Guide. Canada: Jones and Bartlett.

4. Beck, C.T., Reynold, M.A., \& Rutoewski, R. (2013). Maternity blues and postpartum depression. Journal of Obstetric Gynecologic and Neonatal Nursing, 21(4). 42-48.

5. Bobak, I., Lowdermilk, D.L., \& Jensen, M. D. (2005). Buku ajar keperawatan maternitas (edisi 4.). (Maria, A., Wijayarini., \& Peter, I.
Anugerah, Penerjemah.). Jakarta: EGC.

6. Bordbar, M., Faridhosseini., \& Farhad. (2010). Psychoeducation for bipolar mood disorder. Journal: Clinical, Research, Treatment Approaches to Affective Disorder.

7. Bowers E.R.E. \& Corwin. (2013). Nutrition and psychoneuroumunology of postpartum depression. Nutr Res Rev, 25 (1), 180-192.

8. Creswell, J.W. (2009). Research desain: Qualitative \& quantitative aproaches. Jakarta: KIK Press.

9. Creswell, J.W. (2009). Qualitative, quantitative and mixed approaches. Thousand Oaks: Sage Publication

10. Creswell, J.W. (2013). Qualitative inquiry \& quantitative research design: Choosing among five approaches. Thousand Oaks: Sage Publication Ltd.

11. Fisher, J., Tran, T., La, B.T., Kriitmaa, K., Rosenthal, D., \& Tran, T. (2010). Common perinatal mental disorders in northern Vietnam: Community prevalence and health careuse. Bull World Health Organ, 88, 737-745.

12. Fitelson, E., Kim, S., Baker, A.S., \& Leight, K. (2010). Treatment of postpartum depression: Clinical, psychological and pharmacological options. International Journal of Women's Health, 3, 1-14. 
13. Klainin, P., \& Arthur, D.G. (2009). Postpartum depression in asia cultures: A literature review. International Journal of Nursing Studies, 13551373.

14. Leung, B.M.Y., et al. (2013). Prenatal micronutrient supplementation and postpartum depressive symptoms in pregnancy cohort. BMC Pregnancy and Childbirth, 13 (2).

15. Migl, K.S. (2009). The lived experience of prenatal stress and mind-body exercises: Refflection of postpartum women. Dissertation Program Doctor of philosophy. University of Texas Medical. Publicized.

16. Mokhber, N., et al (2011). Effect of suplementation with selenium on postpartum depression: A randomized double blind placebo controlled trial. $J$ Matern Fetal Neonatal Med, 24, 104-108.

17. Nicolson, P. (2010). What is psychological about normal pregnancy. Didownload dari http://www.thepsychologist.bp s.org.uk. Diperoleh tanggal 26 Maret 2015.

18. Notoatmodjo, S. (2010). Metodologi penelitian kesehatan. Jakarta: Rineka Cipta.

19. O'Hara, M.W. (2009). State of science on postpartum depression: What nurse researchers have contribute. Maternal Child Nursing, 33 (2), 121-126.
20. O’Hara, M.N. (2009). Postpartumdepression: What we know. Journal of Clinical Psychology, 65, 1258-1269.

21. Perry, S.E., Hockenberry, M.J., Lowdermilk, D.L., \& Wilson, D. (2010). Maternal child nursing care (4th ed.). Canada: Mosby.

22. Poerwandari, E,K .(2009). Pendekatan kualitatif untuk penelitian perilaku manusia. Depok: LPSP3 Fakultas Psikologi Universitas Indonesia.

23. Stone, S.D., \& Menken, A.E. (2008). Perinatal and postpartum mood disorder's: Perspectives and Treatment Guite for Health Care Practicioner. New York: Springer Publishing Company.

24. Stuart, G.W., \& Laraia, M.T. (2013). Principles and practice of psychiatri nursing (7th ed.). St Louis: Mosby.

25. Sutjhahjo, S.A., Manderson, L., \& Astrbury. J. (2007). Complex emotion's, complex promlem's understanding the experiences of perinatal depression among new mothers in urban Indonesia. Journal Cultur Medicine and Psychiatry, 31, 101-122.

26. Reeder, S.J., Martin, L.L., \& Griffin, D.K. (2011). Keperawatan maternitas: Kesehatan wanita, bayi dan keluarga (edisi 18.) (Yati Afiyanti., Imami Nur Rachmawati., \& Sri djuwitaningsih, Penerjemah.). EGC: Jakarta. 
27. Pillitteri, A. (2010). Maternal and child helath nursing: Care of the childbearing and childrearing family (6rd ed.). USA: Lippincott Williams \& Wilkins Inc. 